\title{
Screening of Coconut Genotypes Against Coconut Eriophyid Mite (Aceria guerreronis Keifer.)
}

\author{
A. S. Bagde ${ }^{1}$, P. D. Patil' and V. V. Pashte ${ }^{3^{*}}$ \\ ${ }^{1}$ Dept. of Entomology, College of Agriculture, Mahatma Phule Krishi Vidyapeeth, Kolhapur, Maharashtra (416 004), India \\ ${ }^{2}$ Dept. of Agricultural Entomology, College of Agriculture,Dr. Balasaheb Kokan Krishi Vidyapeeth, Dapoli, \\ Ratnagiri, Maharashtra (415 712), India \\ ${ }^{3}$ Dept. of Rural Technology, Guru Ghasidas Vishwavidyalaya, Koni, Bilaspur, Chattisgarh (495 009), India
}

\section{Article History}

Manuscript No. AR1486

Received in $3^{\text {rd }}$ November, 2015

Received in revised form $29^{\text {th }}$ January, 2016

Accepted in final form $6^{\text {th }}$ February, 2016

\section{Correspondence to}

"E-mail: pashte.vrushali@gmail.com

\section{Keywords}

Aceria guerreronis, eriophyid mite, screening, coconut genotypes

\begin{abstract}
The coconut genotypes were screened for their level of susceptibility to coconut eriophyid mite. Based on the mean damage Grade Index score none of the coconut genotypes were found to be resistant to eriophyid mite. However the genotypes, Jamica (1.37), BSI (1.51), Lono (1.65), Ganga Bondem (1.67), Banawali yellow long (1.70), Orangedwarf (1.77), Kalpwangi (1.80), F.M.S. (1.88), Guwam (1.93), West coast tall (1.82) CochinNikobar (2.01), Fiji (2.30) and Cochin China (2.35) were found to be moderately resistant to the infestation of eriophyid mite. The genotypes Seychelles (2.88), Phillipines (2.93), T $\times \mathrm{D}$ (3.03), and Andaman Bhadi (3.09) were found to be susceptible to the eriophyid mite infestation. On the other hand the coconut genotypes SanRayman (3.35), Pratap (3.60), Banawali green long (3.60), Sheli gol (3.69), Borino (3.77), Lakshadweep (3.81), Kenya (4.22), Gawati (4.28), were found to be highly susceptible. Among the 26 coconut genotypes screened for their reaction to the coconut eriophyid mite, minimum infestation was observed in the genotypes Jamica, BSI, Lono, Guwam and Orange dwarf which are useful for the coconut growers in minimizing loss caused by eriophyid mite. Thus the impact of coconut eriophyid miteon yield parameters studied under Konkan conditions indicated that as the severity of eriophyid mite infestation increases the total weight, dehusked nut weight, husk weight, kernel weight, shell weight, length, circumference, water content loss of coconut also increase as the different damage grades increase from Grade II to Grade V.
\end{abstract}

\section{Introduction}

Coconut palm, Cocos nucifera Linn. is an important plantation crop grown in India. Among different pests infesting the crop, eriophyid mite, Aceria guerreronis (Keifer) is a serious pest in many coconut growing areas in India. The rapid outbreak of this pest in coconut plantations endangered the copra industry in India, reducing coconut yields and economic profits. This has drawn the attention of farming communities and researchers.

To date the most intractable and most damaging pest of coconut fruit is by far the eriophyid mite, A. guerreronis, commonly called "coconut mite". It was first observed on coconut plants in the state of Guerrero (Mexico) in 1960 (Keifer et al., 1965). The feeding of mite causes scarring of growing nuts resulting in nut malformation and reduced copra yields (Denise et al., 2013). The mite is inhabitant in clusters on the basal portion of the nuts below perianth. Colonization of coconuts by coconut mites takes place shortly after fertilization (Moore et al., 1989). Coconut mite populations peak on 3 to 6-month old nuts, after which, the numbers decline sharply so that nuts over nine months old have relatively low populations (Moore and Alexander, 1987). Coconut mites tend to leave nuts two to three months before the nuts are fully developed or when damage to the pericarp exceeds $15 \%$ because there is no renewal of meristematic tissues. In addition, damaged nut surfaces tend to secrete resin which traps and kills the mites (Moore and Alexander, 1987).

The incidence of the coconut mite was reported by several parts of the world (Keifer, 1965; Mariau, 1977; Howard et al., 1990). The affected area has been estimated by several workers in the various parts of south India (Haq, 1999; Reddy and Naik, 2000; Nair, 2000; Arulmozhi et al., 2002; Kirathiga et 
al., 2002; Nair et al., 2002; Natarajan et al., 2002; Ramaraju et al., 2002; Sujatha and Rao, 2004; Nair et al., 2005; Sumangala and Haq, 2005; Sujatha et al., 2008; Begum and Babu, 2013;Kaimal, 2013). The pest is recently reported in the state of Maharashtra (Bagde and Pashte, 2014; Bagde et al., 2014, Bagde and Pashte, 2016) particularly in the Konkan region. However, the information on the varietal interaction with the coconut perianth mite is scarce under costal Maharashtra conditions, which is major coconut growing part of south India. Hence, the present studies were carried out to judge the level of susceptibility of coconut genotypes against coconut mite.

\section{Materials and Methods}

The reaction of selected twenty six coconut genotypes available at Regional coconut research station, Bhatye, Ratnagiri $\left[16.9800^{\circ} \mathrm{N}, 73.3000^{\circ} \mathrm{E}\right]$, Maharashtra, India were screened for their level of susceptibility to coconut eriophyid mite during 2008-2009. The nuts harvested from each genotype during each harvest were visually scored for the nut surface area damage. The harvested nuts were distributed in to different damage grades as given by Julia and Mariau (1979) as described below.

\subsection{Classification of coconut palms in different category}

After calculating mean damage Grade Index, the different genotypes were classified into four categories as given by Julia and Mariau (1979) and accordingly the genotypes were classified into resistant, moderately resistant, susceptible and highly susceptible as given below (Table 1).

Table 1: Genotype categories as given by Julia and Mariau (1979)

\begin{tabular}{lc}
\hline Mean damage grade index score & Classification \\
\hline $0-1.0$ & Resistant \\
$1.1-2.5$ & Moderately resistant \\
$2.6-3.5$ & Susceptible \\
$3.6-5.0$ & Highly susceptible \\
\hline
\end{tabular}

\subsection{Estimation of losses}

To estimate the yield loss due to the attack of eriophyid mite, a total of 5 nuts were observed in each category (1-5 Scale adopted by Julia and Mariau, 1979) and observed for total weight, dehusked weight, husk weight, kernel weight, length, circumference, water content, shell weight.

\subsubsection{Loss in total weight}

$\begin{aligned} & \text { Percentage reduction } \\ & \text { over Grade I }\end{aligned}=\frac{\begin{array}{l}\text { Av. wt. of whole } \\ \text { nut Grade I }\end{array}}{\text { Av. wt of whole nut in Grade I }} \begin{aligned} & \text { Av. wt. in } \\ & \text { respective grades }\end{aligned} \times 100$
2.2.2. Loss in dehusked weight

\begin{tabular}{|c|c|}
\hline $\begin{array}{l}\text { Percentage } \\
\text { reduction }\end{array}$ & $\begin{array}{l}\begin{array}{l}\text { Av. wt. of dehusked } \\
\text { nut in Grade I }\end{array} \\
\text { respective grades }\end{array}$ \\
\hline
\end{tabular}

\subsubsection{Loss in husk weight}

$\begin{aligned} & \text { Percentage } \\ & \text { reduction } \\ & \text { over Grade I }\end{aligned}=\frac{\begin{array}{l}\text { Av.wt of husk of nut } \\ \text { in Grade I }\end{array}}{\text { Av. wt. of husk in Grade I }} \begin{aligned} & \text { Avt. in } \\ & \text { respective grades }\end{aligned} \times 100$

\subsubsection{Loss in kernel weight}

Av. kernel wt. of Av. wt. in

$\begin{aligned} & \text { Percentage reduction } \\ & \text { over Grade I }\end{aligned}=\frac{\text { nut in Grade I }}{\text { Av. wt. of kernels nut in Grade I }} \times 100$

2.2.5. Loss in length

$\begin{aligned} & \text { Percentage reduction } \\ & \text { over Grade I }\end{aligned}=\frac{\begin{array}{l}\text { Av.length of } \\ \text { nut in Grade I }\end{array}-\begin{array}{l}\text { Av. wt. in } \\ \text { respective grades }\end{array}}{\text { Av. length of nut in Grade I }} \times 100$ 2.2.6. Loss in circumference

Av. circumference Av. wt. in

Percentage reduction of nut in Grade I ${ }^{-}$respective grades over Grade I $=\frac{\text { Av.circumference of nut in Grade I }}{\times}$

2.2.7. Loss in water content

Av. water content Av. wt. in

Percentage reduction $=\frac{\text { of nut in Grade I }{ }^{-} \text {respective grades }}{\times 100}$ over Grade I $=\overline{\text { Av.water content of nut in Grade I }}$

2.2.8. Loss in shell weight

$\begin{aligned} & \text { Percentage reduction } \\ & \text { over Grade I }\end{aligned}=\frac{\begin{array}{l}\text { Av. shell wt. of } \\ \text { nut in Grade I }\end{array}}{\text { Av. shell wt. of nut in Grade I }} \times \begin{aligned} & \text { Av. wt. in } \\ & \text { respective grades }\end{aligned} \times 100$

\section{Results and Discussion}

3.1. Screening of coconut genotypes against eriophyid mite (A.guerreronis) in Konkan region

The mite infestation (\%) on different coconut genotypes (Table 2) existing at Regional Coconut Research Station, Bhatye, Dist. Ratnagiri varied from 33.34 to 100. Max. nuts were infested in Kenya, Seychelles Borino, San, Raymon, $T \times D$, Pratap, Fiji, B. greenlong, Lakshadweep (100\%). The minimum percentage nuts were infested in Jamica (33.34\%) followed by BSI (40.82). The extent of damage caused by mite in each genotype is shown in Table 1. Based on the mean damage Grade Index score none of the coconut genotypes was found to be resistant to eriophyid mite. However, the genotypes, Jamica, BSI, Lono, Ganga Bondem, Banawali yellow long, Orange dwarf, Kalpwangi, F.M.S., Guwam, West coast tall, Cochin Nikobar, Fiji and Cochin China were found to be moderately resistant to the infestation of eriophyid mite. The genotypes Seychelles, Phillipines, $\mathrm{T} \times \mathrm{D}$ and Andaman Bhadi were found 


\begin{tabular}{|c|c|c|c|c|c|c|c|c|c|}
\hline \multirow{2}{*}{$\begin{array}{l}\text { Sr. } \\
\text { no. }\end{array}$} & \multirow[t]{2}{*}{ Cultivars } & \multicolumn{5}{|c|}{ Nuts in each damage category (\%) } & \multirow{2}{*}{$\begin{array}{c}\text { Total } \\
\text { no. } \\
\text { of nuts }\end{array}$} & \multirow{2}{*}{$\begin{array}{c}\text { Nuts } \\
\text { damaged by } \\
\text { mite }(\%)\end{array}$} & \multirow{2}{*}{$\begin{array}{c}\text { Mean } \\
\text { damage grade } \\
\text { index score }\end{array}$} \\
\hline & & Grade I & Grade II & Grade III & Grade IV & Grade V & & & \\
\hline 1. & Jamica & 66.66 & 29.62 & 3.70 & 0.00 & 0.00 & 54 & 33.34 & 1.37 \\
\hline 2. & BSI & 59.18 & 30.61 & 10.20 & 0.00 & 0.00 & 49 & 40.82 & 1.51 \\
\hline 3. & Kenya & 0.00 & 0.00 & 22.22 & 33.33 & 44.44 & 63 & 100.0 & 4.22 \\
\hline 4. & Orange dwarf & 43.54 & 35.48 & 20.96 & 0.00 & 0.00 & 62 & 56.46 & 1.77 \\
\hline 5. & Guwam & 51.85 & 31.48 & 16.66 & 0.00 & 0.00 & 54 & 48.15 & 1.93 \\
\hline 6. & Kalpwangi & 45.65 & 28.26 & 26.08 & 0.00 & 0.00 & 46 & 54.35 & 1.80 \\
\hline 7. & Saiachlishe & 0.00 & 37.77 & 35.55 & 26.66 & 0.00 & 45 & 100.0 & 2.88 \\
\hline 8. & Lono & 48.93 & 36.17 & 14.89 & 0.00 & 0.00 & 47 & 51.07 & 1.65 \\
\hline 9. & CochinNicobar & 46.66 & 16.66 & 25.00 & 11.66 & 0.00 & 60 & 53.34 & 2.01 \\
\hline 10. & Cochin China & 29.82 & 31.57 & 19.29 & 12.28 & 7.01 & 57 & 70.18 & 2.35 \\
\hline 11. & Borino & 0.00 & 0.00 & 40.81 & 40.81 & 18.36 & 49 & 100.0 & 3.77 \\
\hline 12. & Sun Raymon & 0.00 & 17.64 & 43.13 & 25.49 & 13.72 & 51 & 100.0 & 3.35 \\
\hline 13. & $\mathrm{~T} \times \mathrm{D}$ & 0.00 & 38.18 & 29.09 & 23.63 & 9.09 & 55 & 100.0 & 3.03 \\
\hline 14. & Ganga Bondem & 47.16 & 41.50 & 7.54 & 3.77 & 0.00 & 53 & 100 & 1.67 \\
\hline 15. & Shelai Gol & 0.00 & 0.00 & 40.38 & 50.00 & 9.61 & 52 & 52.84 & 3.69 \\
\hline 16. & Gawati & 0.00 & 0.00 & 14.28 & 42.85 & 42.85 & 49 & 100 & 4.28 \\
\hline 17. & Banawali Yellow Long & 50.00 & 30.00 & 20.00 & 0.00 & 0.00 & 50 & 100 & 1.70 \\
\hline 18. & B.Yellow Round & 0.00 & 20.28 & 60.86 & 15.94 & 2.89 & 69 & 50 & 3.01 \\
\hline 19. & Pratap & 0.00 & 0.00 & 56.92 & 26.15 & 16.92 & 65 & 100 & 3.60 \\
\hline 20. & B.Green Long & 0.00 & 0.00 & 54.16 & 31.25 & 14.58 & 48 & 100 & 3.60 \\
\hline 21. & Fiji & 0.00 & 76.92 & 15.38 & 7.69 & 0.00 & 52 & 100 & 2.30 \\
\hline 22. & Philippines & 0.00 & 27.65 & 55.31 & 12.76 & 4.25 & 47 & 100 & 2.93 \\
\hline 23. & Lakshadweep & 0.00 & 0.00 & 37.73 & 43.39 & 18.86 & 53 & 100 & 3.81 \\
\hline 24. & F.M.S. & 43.18 & 29.54 & 22.72 & 4.54 & 0.00 & 44 & 56.82 & 1.88 \\
\hline 25. & West Coast Tall & 31.70 & 56.09 & 9.75 & 2.43 & 0.00 & 41 & 68.30 & 1.82 \\
\hline 26. & Andaman Bhadi & 0.00 & 30.23 & 39.53 & 20.9 & 9.30 & 43 & 100 & 3.09 \\
\hline
\end{tabular}

to be susceptible to the eriophyid mite infestation. On the other hand the coconut genotypes SunRayman, Pratap, Banawali green long, Sheli gol, Borino, Lakshadweep, Kenya, Gawati, were found to be highly susceptible. The results of present investigations are in conformity with the results of Muthia and Bhaskaran (1999) who found that Cochin China, Ganga Bondem recorded minimum percentage of nuts damaged by the mite. Girisha and Nandihalii (2009) also recorded least damage grade (1.40) in Gangabondem coconut. Similarly Muthiah and Rajarathiam (2002) recorded that BSI was moderately tolerant to the coconut mite attack.

\subsection{Estimation of yield loss}

Impact of coconut eriophyid mite A. gurreronis on yield parameters studied under Konkan conditions are presented in Table 3 to 7. Losses in coconut due to eriophyid mite were studied. It was found that the losses of nut in Grade II were, $3.40 \%$ in total weight, $2.40 \%$ in dehusked nut weight, $5.54 \%$ in husk weight, $6.26 \%$ in shell weight, $4.12 \%$ in kernel weight, $4.10 \%$ in length, $9.56 \%$ in circumference and $5.95 \%$ in water content over Grade I (healthy nut).

The losses observed in nut of Grade III were, $8.10 \%$ in total weight, $6.72 \%$ in dehusked nut weight, $10.9 \%$ in husk weight, $10.10 \%$ in shell weight, $9.23 \%$ in kernel weight, $16.07 \%$ in length, $13.07 \%$ in circumference and $15.85 \%$ in water content over Grade I (healthy nut). In Grade IV losses were observed as $23.70 \%$ in total weight, $25.39 \%$ in dehusked nut weight, $20.51 \%$ in husk weight, $14.67 \%$ in shell weight, $16.61 \%$ in kernel weight, $24.80 \%$ in length, $21.39 \%$ in circumference and $27.30 \%$ in water content over Grade I.

The losses observed in nut of Grade V were, $47.60 \%$ in total 


\begin{tabular}{|c|c|c|c|c|c|c|}
\hline \multirow[t]{2}{*}{$\begin{array}{l}\text { Sr. } \\
\text { no. }\end{array}$} & \multirow{2}{*}{$\begin{array}{l}\text { Para } \\
\text { meters }\end{array}$} & \multicolumn{5}{|c|}{ Grade wise measurements nut ${ }^{-1}$} \\
\hline & & $\begin{array}{c}\text { Grade } \\
\text { I }\end{array}$ & $\begin{array}{c}\text { Grade } \\
\text { II }\end{array}$ & $\begin{array}{c}\text { GradeI } \\
\text { II }\end{array}$ & $\begin{array}{c}\text { Grade } \\
\text { IV }\end{array}$ & $\begin{array}{c}\text { Grade } \\
\mathrm{V}\end{array}$ \\
\hline 1. & $\begin{array}{l}\text { Total } \\
\text { wt. (g) }\end{array}$ & 860.67 & 830.90 & 790.67 & 656.27 & 450.60 \\
\hline 2. & $\begin{array}{l}\text { Nut wt. } \\
\text { without } \\
\text { husk (g) } \\
\text { (dehus- } \\
\text { ked nut) }\end{array}$ & 570.23 & 556.57 & 531.90 & 425.43 & 314.17 \\
\hline 3. & $\begin{array}{l}\text { Husk } \\
\text { wt. (g) }\end{array}$ & 290.43 & 274.33 & 258.77 & 230.83 & 136.40 \\
\hline 4. & $\begin{array}{l}\text { Shell } \\
\text { wt. (g) }\end{array}$ & 100.60 & 94.30 & 90.43 & 85.83 & 71.53 \\
\hline 5. & $\begin{array}{l}\text { Kernel } \\
\text { wt. (g) }\end{array}$ & 168.33 & 161.40 & 152.80 & 140.37 & 123.43 \\
\hline 6. & $\begin{array}{l}\text { Length } \\
(\mathrm{cm})\end{array}$ & 24.82 & 23.81 & 20.83 & 18.67 & 16.50 \\
\hline 7. & $\begin{array}{l}\text { Circum- } \\
\text { ference } \\
(\mathrm{cm})\end{array}$ & 31.34 & 28.33 & 27.23 & 24.60 & 16.97 \\
\hline 8. & $\begin{array}{l}\text { Water } \\
\text { content } \\
(\mathrm{ml})\end{array}$ & 184.37 & 173.40 & 155.13 & 134.03 & 112.50 \\
\hline
\end{tabular}

Table 4: Reduction in yield parameters over healthy nuts of Grade I due to eriophyid mite infestation on coconut parameters

\begin{tabular}{llccc}
\hline \multirow{2}{*}{$\begin{array}{l}\text { Sr. } \\
\text { no. }\end{array}$} & Parameters & \multicolumn{3}{c}{ \% reduction in Grade II over } \\
& & Grade I & Grade II & Reduction \\
\cline { 3 - 5 } & & & & $(\%)$ \\
\hline 1. & Total weight (g) & 860.67 & 830.90 & 3.4 \\
2. & Nut wt. without husk & 570.23 & 556.57 & 2.4 \\
& (g) (dehusked nut) & & & \\
3. & Husk weight (g) & 290.43 & 274.33 & 5.54 \\
4. & Shell weight (g) & 100.60 & 94.30 & 6.26 \\
5. & Kernel weight (g) & 168.33 & 161.40 & 4.12 \\
6. & Length (cm) & 24.82 & 23.81 & 4.10 \\
7. & Circumference (cm) & 31.34 & 28.33 & 9.56 \\
8. & Water content (ml) & 184.37 & 173.40 & 5.95 \\
\hline
\end{tabular}

weight, $44.99 \%$ in dehusked nut weight, $53.00 \%$ in husk weight, $28.89 \%$ in shell weight, $26.67 \%$ in kernel weight, $32.52 \%$ in length, $31.65 \%$ in circumference and $38.98 \%$ in
Table 5: Reduction in yield parameters over healthy nuts of Grade I due to eriophyid mite infestation on coconut parameters

\begin{tabular}{|c|c|c|c|c|}
\hline \multirow[t]{2}{*}{$\begin{array}{l}\text { Sr. } \\
\text { no. }\end{array}$} & \multirow[t]{2}{*}{ Parameters } & \multicolumn{3}{|c|}{$\begin{array}{l}\% \text { reduction in Grade III over } \\
\text { Grade I }\end{array}$} \\
\hline & & Grade I & Grade III & $\begin{array}{l}\text { Reduction } \\
(\%)\end{array}$ \\
\hline 1. & Total wt. (g) & 860.67 & 790.67 & 8.1 \\
\hline 2. & $\begin{array}{l}\text { Nut wt. without husk } 5 \\
\text { (g) (dehusked nut) }\end{array}$ & 570.23 & 531.90 & 6.72 \\
\hline 3. & Husk weight (g) & 290.43 & 258.77 & 10.9 \\
\hline 4. & Shell weight (g) & 100.60 & 90.43 & 10.10 \\
\hline 5. & Kernel weight (g) & 168.33 & 152.80 & 9.23 \\
\hline 6. & Length $(\mathrm{cm})$ & 24.82 & 20.83 & 16.07 \\
\hline 7. & Circumference $(\mathrm{cm})$ & 31.34 & 27.23 & 13.07 \\
\hline 8. & Water content (ml) & 184.37 & 155.13 & 15.85 \\
\hline \multicolumn{5}{|c|}{$\begin{array}{l}\text { Table 6: Reduction in yield parameters over healthy nuts } \\
\text { of Grade I due to eriophyid mite infestation on coconut } \\
\text { parameters }\end{array}$} \\
\hline \multirow[t]{2}{*}{$\begin{array}{l}\text { Sr. } \\
\text { no. }\end{array}$} & \multirow[t]{2}{*}{ Parameters } & \multicolumn{3}{|c|}{$\begin{array}{c}\% \text { reduction in Grade IV } \\
\text { over Grade I }\end{array}$} \\
\hline & & $\begin{array}{c}\text { Grade } \\
\text { I }\end{array}$ & $\begin{array}{l}\text { Grade } \\
\text { IV }\end{array}$ & $\begin{array}{l}\text { Reduction } \\
(\%)\end{array}$ \\
\hline 1. & Total wt. (g) & 860.67 & 656.27 & 23.7 \\
\hline 2. & $\begin{array}{l}\text { Nut wt. without husk (g) } \\
\text { (dehusked nut) }\end{array}$ & 570.23 & 425.43 & 25.39 \\
\hline 3. & Husk weight (g) & 290.43 & 230.83 & 20.51 \\
\hline 4. & Shell weight (g) & 100.60 & 85.83 & 14.67 \\
\hline 5. & Kernel weight (g) & 168.33 & 140.37 & 16.61 \\
\hline 6. & Length $(\mathrm{cm})$ & 24.82 & 18.67 & 24.80 \\
\hline 7. & Circumference $(\mathrm{cm})$ & 31.34 & 24.60 & 21.39 \\
\hline 8. & Water content $(\mathrm{ml})$ & 184.37 & 134.03 & 27.30 \\
\hline
\end{tabular}

water content over Grade I (healthy nut). Thus the impact of coconut eriophyid miteon yield parameters studied under Konkan conditions indicated that as the severity of eriophyid mite infestation increases the total weight, dehusked nut weight, husk weight, kernel weight, shell weight, length, circumference, water content loss of coconut also increases as the different damage grades increases from Grade II to Grade V. The most crucial aspect of mite attack has been attributed to the loss in copra weight, estimated to almost reach 32\% (Haq and Sobha, 2010). The present findings are in conformity with (Muralidharan et al., 2001) who reported $30.94 \%$ and $41.74 \%$ losses in terms of copra and husk, respectively in Alappuzha district of Kerala. Beevi et al., 2003 also reported that losses 


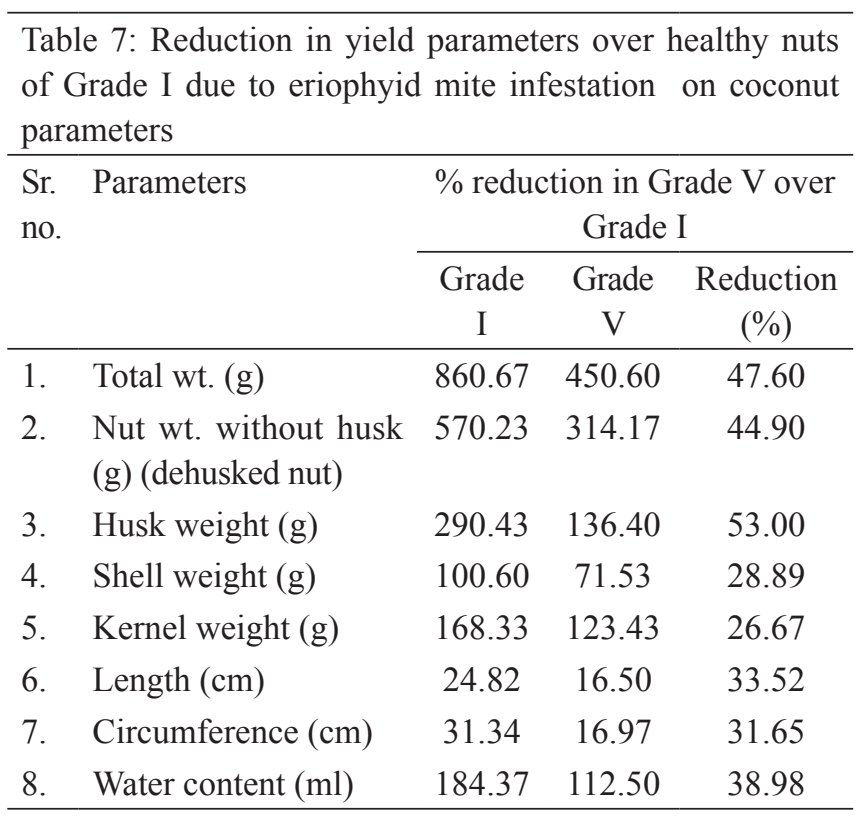

due to husk damage have been estimated particularly because of the reduction of fiber length by and the consequent extra cost for de-husking.

\section{Conclusion}

Coconut genotypes Jamica, BSI, Lono, Ganga Bondem, Banawali yellow long, Orange dwarf, Kalpwangi, F.M.S., Guwam, West coast tall, Cochin Nikobar, Fiji and Cochin China were found to be moderately resistant to the infestation of eriophyid mite, which are useful for the coconut growers in minimizing loss caused by eriophyid mite. Thedata regarding the tolerance level helpful in breeding programs of coconut cultivars for development of resistant varieties to mite infestation.

\section{References}

Arulmozhi Fernando, A.K., Moraes, G.J., Wickramananda, I.R., 2002. Containing the eriophyid mite on coconutan approach. Proceeding of the International workshop on coconut mite Aceria guerreronis, Coconut Research Institute, Sri Lanka, 50-53.

Bagde, A.S., Patil, P.D., Pashte, V.V., 2014. Studies on efficacy of neem biopesticides against eriophyid mite (Aceria guerreronis Keifer). The Bioscan 9(1), 341-346.

Bagde, A.S., Pashte, V.V., 2014. A survey of infestation of coconut eriophyid mite, Aceria guerreronis Keifer in Konkan region of Maharashtra (India). The Bioscan 9(1), 571-576.

Bagde, A.S., Pashte, V.V., 2016. Efficacy of neem biopesticides against eggs of coconut eriophyid mite, (Aceria guerreronis Keifer). Advances in Life Sciences 5(4), 1436-1448.
Beevi, S., Mathew, T.B., Bai, H., Saradamma, K., 2003. Status of eriophyid mite in Kerala. In: Coconut Eriophyid Mite Issues and Strategies. In: Singh, H.P., Rethinam, P. (Eds.), Proceedings of the International Workshop On Coconut Mite. CDB, Kochi, 64-75.

Begum, N., Babu, R., H.N., 2013. Management of coconut perianth mite Aceria guerreronis by using botanicals/ biopesticides in Machenahalli near Shivamogga, Karnataka. Environment and Ecology 31, 569-572.

Denise, N., Manoel, G.C.G., Nayanie, S.A., Gilberto, J.M., 2013. A review of the status of the coconut mite, Aceria guerreronis (Acari: Eriophyidae), a major tropical mite pest. Experimental and Applied Acarology 59(1-2), 67-94.

Girisha, R.C., Nandihalli, B.S., 2009. Seasonal abundance and varietal reaction of coconut perianth mite, Aceria guerreronis Keifer in Dharwad area. Karnataka Journal Agricultural Science 22(3), 606-608.

Haq, M.A., 1999. Amazing trend in distribution of the coconut mite Aceria guerreronis in Penisular India and adjacent island. Entomon 24, 371-379.

Haq, M.A., Sobha, T.R., 2010. Weight loss of copra due to infestation of Aceria guerreronis. In: Sabelis, M.W., Bruin, J. (Eds), Proceedings of the $12^{\text {th }}$ International Congress of Acarology, Amsterdam, 509-510.

Howard, F.W., Abreu-Rodrigeuz, E., 1990. Tightness of the perianth of coconut in relation to infestation by coconut mites. Florida Entomologist 74, 358-361.

Julia, J.F., Mariau, D., 1979. Nouvelles recherches en cote d ivoire sur Eriophyes guerreronis K., acarien ravageur des noix du cocotier. Oleagineux 34, 181-189.

Kaimal, S.G., 2013. The Coconut Mite, Aceria Guerreronis Keifer (Acari: Eriophydae)-A Plague in Kerala. International Journal of Science and Research 4(3), 693-696.

Keifer, H.H., 1965.Eriophyid studies. Bureau Entomology, California Department of Agriculture, Sacramento, 20.

Kiruthiaga, K.S., Shanmugamathan, E., Vanitha, N., Mariammal, V., Senthilnathan, S., 2002. Eriophyid mite infestation on coconut problems focus. Indian Coconut Journal 33, 15-17.

Mariau, D., 1977. Aceria (Eriophyes) guerreronis an important ravageur des cocoteraies africaines et americaines. Oleagineux 32, 101-111.

Moore, D., Alexander, L., 1987. Aspects of migration and colonization of the coconut palm by the coconut mite, A. guerreronis (Keifer) (Acari: Eriophyidae). Bulletin of Entomological Research 77(4), 641-50.

Moore, D., Alexander, L., Halls, R.A., 1989. The coconut mite, Eriophyes guerreronis Keifer in St. Lucia: yield losses and attempts to control it with acaricide, polybutene and 
Hirsutell fundus. Tropical Pest Management 35, 83-89.

Muralidharan, K., Mathew, J., Thampan, C., Amaranth, C.H., Anitha Kumari, P., Mohan, C., Vijayakumar, K., Sairam, C.V., Nair, C.P.R., Arulraj, S., 2001. Pilot sample survey on the incidence and yield loss due to eriophyid mite on coconut in Alappuzha District. Indian Coconut Journal 32, 28-32.

Muthiah, C., Bhaskaran, R., 1999. Screening of coconut phenotypes and management of eriophyid mite Aceria guerreronis (Eriophyidae: Acari) in Tamil Nadu. Indian Coconut Journal 30(6), 10-11.

Muthiah, C., Rajarathiam, S., 2002. Screening of coconut genotypes/hybrids and management of eriophyid mite on coconut. In: Proceedings of the $15^{\text {th }}$ plantation crop symposium placrosym XV, Mysore, India, 10-13 December, 583-587.

Nair, C.P.R., 2000. Studies on coconut eriophyid mite Aceria guerreronis K. in India. In: Proceedings of the International workshop on coconut eriophyid mite (Aceria gurerreronis). Coconut Research Institute, Sri Lanka, 9-12.

Nair, C.P.R., Fernando, C.P., Moraes, G.J., Wickaramananda, J.R., 2002. Seasonal abundance of coconut mite. In: Proceedings of the international workshop on coconut mite Aceria guerreronis, Coconut Research institute Sri Lanka, 6-8 January, 9-12.

Nair, C.P.R., Rajan, P., Mohan, C., 2005, Coconut eriophyid mite Aceria guerreronis Keifer-An overview. Indian Journal of Plant Protection 33(1), 1-10.

Natrajan, K., Ramraju, K., Babu, P.C.S., Palaniswamy, S., 2002. Studies on coconut eriophyid mite, Aceria guerreronis Keifer in Tamil Nadu, India. In: Proceedings of the International workshop on coconut mite Aceria guerreronis, Coconut Research Institute, Sri Lanka. 6-8 January, 18, 13-31.

Ramaraju, K., Natrajan, K., Babu, P.C.S., Planiswmy, S., Rabindra, R.J., Fernando, L.C.P., Moraes, G.J., Wickramananda I.R., 2002. Studies on coconut eriophyid mite, Aceria guerreronis Keifer in Tamil Nadu, India. In: Proceedings of the International workshop on coconut mite Aceria guerreronis. Coconut Research Institute Sri Lanka. 6-8 January, 18, 13-31.

Reddy, L.S., Naik, S.L., 2000. Spread of Eriophyid mites in to the coconut gardens of Chittoor district, Andhra Pradesh. Indian Coconut Journal 31, 8-9.

Sujatha, A., Chalapathi Rao, N.B.V., Varma, N.R.G., Reddy, R.D., 2008. Influence of weather parameters on population build-up of coconut Eriophyid Mite. Annals of Plant Protection Sciences 16(1), 203-267.

Sujatha, S., Rao, C., 2004. Surveillance of coconut plant. Indian Coconut Journal 27, 14-15.

Sumangala, K., Haq, M.A., 2005. Diurnal periodicity and dispersal of coconut mite, Aceria guerreroneis Keifer. Journal of Entomological Research 29(3), 303-307. 